\title{
Chapter 1: Russia's Foreign Food Trade: An Historical Survey
}

\author{
Stephen K. Wegren
}

\section{INTRODUCTION}

Russia's role in the international food trade system and impact on that system has gone through different phases over time. In the pre-World War I period, Russia was Europe's largest grain exporter, especially wheat. During the Soviet period from the 1970s onward the USSR impacted the international food trade system by entering the global market to purchase grain to compensate for domestic shortfalls. Recently, Russia has returned to its historical place and currently plays a significant role in the international food trade system as a global supplier of wheat. Russia has been the leading wheat exporter in the world during six of the past seven agricultural years, surpassing the United States. Russia's contemporary role as a leading grain exporter is juxtaposed to lingering impressions of the Soviet Union as a grain importer to feed people and cattle. The change in Russia's role in international agricultural trade is attributable to several factors: the liberalisation of the economy after 1992; the emergence of private sector entrepreneurs who propel economic development much

\section{S. K. Wegren $(\bowtie)$}

Southern Methodist University, Dallas, TX, USA

e-mail: swegren@smu.edu

(C) The Author(s) 2022

S. K. Wegren and F. Nilssen (eds.), Russia's Role in the Contemporary

International Agri-Food Trade System, Palgrave Advances

in Bioeconomy: Economics and Policies,

https://doi.org/10.1007/978-3-030-77451-6_2 
as American inventors and investors were driving forces in the American food industry in the early twentieth century; a significant rebound in agricultural production; an increase in the state ambitions for international prestige; and the emergence of mega-farms that are modern, globally competitive, and use advanced technology to achieve high efficiency. These processes work together to produce a food revolution in food supply, distribution, and retailing that has led to unprecedented consumer choice about how and where to obtain food. ${ }^{1}$

The purpose of this chapter is to survey Russia's role in international agricultural trade and how that role has changed over time. The chapter sheds light on three related questions. (1) To what extent has Russia's role as a significant player in the international food trade system changed over time? (2) To what extent has Russia been integrated to world food markets and how has the degree of integration changed over time? (3) What is the significance of those changes? The goal is to provide historical context for the chapters that follow which focus on the contemporary period since 2014 .

\section{Analytical Framework}

Countries engage in food trade for a variety of reasons. History shows that nations engage in food trade because it yields several benefits. In the economic realm, a food exporting country may have a comparative advantage and is able to sell its food at an attractive price, thereby earning foreign currency by meeting demand in another country. Or maybe a country wants to reduce its food surplus and support domestic prices. In the political realm, countries export food to strengthen or maintain friendly relations. Exports may be used to bind other nations to the exporter; in this respect food exports are useful for maintaining alliances and empires. Food exports are also used to build international status and prestige. And food may be exported as aid as a means to expand soft power abroad. In the security realm, food exports may help an ally or withheld to punish an adversary. These motivations are not exclusive and several may be true simultaneously.

Although protectionism throughout the world has been on the rise since 2016, countries may benefit from food imports. For example, a country may have a comparative disadvantage for a given commodity and therefore it saves money by importing. A country may experience chronic or temporary supply shortages and needs to import food to avoid hunger 
or political instability. A country may import food to benefit consumers by opting for a cheaper alternative to domestic production, or simply to allow consumers more choice. A country may import a commodity or commodities that it cannot produce itself. Or a country may import food as part of an alliance network in which trade serves to maintain that alliance.

My framework to analyse Russia's food trade behaviour consists of four variables, with responses ranging from low to high: (1) frequency of entrance into the global food market; (2) degree of food trade protectionism; (3) degree of integration with Western global trading institutions; and (4) degree of involvement in the global food market. The variables are defined as follows. The global food market consists of trading institutions defined and created by the West, such as General Agreement on Trade and Tariffs (GATT) or World Trade Organisation (WTO). Frequency is defined as how often Russia enters the global food market in a given timeframe; the range is periodic to consistent entrance. Degree of protectionism concerns whether food trade protectionism was high or low, encompassing both tariff and non-tariff barriers. Degree of integration refers to whether Russia was a full member of global trading institutions or acted outside of them. Degree of involvement concerns the volume of Russia's food imports and exports with Western nations. Time is overlaid with those variables and the framework is illustrated in Table 1 .

The table displays patterns of continuity and change. Since the 1980s, Russia has had high frequency of entrance into the global food market, mostly as a food importer. Its degree of involvement in the global food market has been high as a consistent food importer and recently as a food exporter. Discontinuity since the 1980s is found in the degree of agricultural protectionism, degree of integration with global trade institutions, and Russia's emergence as a significant grain exporter since 2014.

\section{INSTITUTIONS FOR INTERNATIONAL Agri-Food Trade}

The Soviet Union participated in the Bretton Woods conference in 1944 that led to trading rules established by the 1947 General Agreement on Trade and Tariffs (GATT). Ultimately, the Soviet Union chose not to join GATT or other institutions created out of the conference such as the World Bank or International Monetary Fund (IMF). The GATT allowed 
Table 1 Framework for analysis of Russia's food trade behaviour

\begin{tabular}{|c|c|c|c|c|c|}
\hline & $1970 s$ & $1980 s$ & $1990 s$ & $2000-2013$ & 2014-2020 \\
\hline $\begin{array}{l}\text { Frequency of } \\
\text { entrance into } \\
\text { global food } \\
\text { market }\end{array}$ & Low & High & High & High & High \\
\hline $\begin{array}{l}\text { Agricultural } \\
\text { protectionism }\end{array}$ & High & High & $\begin{array}{c}\text { Transition } \\
\text { from high to } \\
\text { low }\end{array}$ & Low & $\begin{array}{l}\text { Transition } \\
\text { from low to } \\
\text { selectively high }\end{array}$ \\
\hline $\begin{array}{l}\text { Degree of } \\
\text { integration with } \\
\text { Western trade } \\
\text { institutions }\end{array}$ & Low & Low & Low & $\begin{array}{c}\text { Transition } \\
\text { from low to } \\
\text { high }\end{array}$ & $\begin{array}{c}\text { Transition } \\
\text { from high to } \\
\text { low }\end{array}$ \\
\hline $\begin{array}{l}\text { Degree of } \\
\text { involvement in } \\
\text { global food } \\
\text { market, } \\
\text { including: }\end{array}$ & Low & High & High & High & High \\
\hline Food imports & Periodic & Consistent & Consistent & Consistent & Consistent \\
\hline Food exports & Low & Low & Low & $\begin{array}{l}\text { Transition } \\
\text { from low to } \\
\text { high }\end{array}$ & High \\
\hline
\end{tabular}

Source Author's analysis

countries in the developed world to use non-tariff barriers, quotas, tariffs on imports, and export subsidies to protect their agricultural sectors. Soviet participation in GATT was on the table in 1972 when the United States proposed entry as a complement to détente, but the Soviet leadership declined the invitation. ${ }^{2}$ The Soviet Union also chose not to participate in the Tokyo Round of negotiations that began in 1973.

The importance of the Soviet Union being outside of GATT was that it allowed non-application countries to be denied most-favoured nation status (MFN). Therefore, the USSR's non-application status meant that the U.S. Congress could extend or withhold MFN for the Soviet Union, which in turn allowed trade to be politicised as was evident with the 1974 Jackson-Vanik Amendment which linked MFN to Jewish emigration from the USSR. When the Soviets balked at this linkage, MFN was denied. Henceforth, MFN would only be granted after annual certification of the Soviet Union's behaviour. It was not until 1992 that post-Communist Russia was given permanent MFN. 
The Tokyo Round of negotiations in 1973 revealed three different approaches to agricultural trade among developed countries. First, efficient producers wanted negotiations to lead to freer agricultural trade, while inefficient producers preferred stable markets through regulation and minimum commodity prices. Second, the European Community preferred to negotiate agricultural products separately from industrial products, a disagreement that would not be settled until 1977. Third, the United States favoured a reduction of tariffs on all products, including agriculture, and also supported a prohibition on direct export subsidies for all products. This position was rejected by the European Community. ${ }^{3}$

Meanwhile, the use of trade 'exceptions' by the United States, Western Europe countries, and Japan meant that the general trend in reducing trade barriers as mandated by GATT did not affect agricultural trade. For example, the U.S. Congress pressured GATT members to allow tariffs if imports caused 'domestic injury' to agriculture (Sect. 22), or allowed GATT rules to be suspended if needed in order to preserve health, safety, or national security. ${ }^{4}$ Thus, the agricultural sector in developed nations remained more protected than industry and manufacturing. Over time, however, the cost of farm subsidies and protectionism grew onerous, rising to $\$ 300$ billion annually by the mid-1980s in OECD countries, with around 40 percent of farm income coming from subsidies. ${ }^{5}$

The cost of agricultural protectionism to U.S. taxpayers was also considerable and financial pressures led to support for liberalised agricultural trade. During the 1970s the United States quadrupled the value of its agricultural exports from \$6.7 billion USD in fiscal 1970 to over \$27 billion USD in fiscal 1978. As a result, the U.S. share of world agricultural trade increased from 13.5 percent in 1970 to 17 percent in 1978. In 1981, U.S. agricultural exports reached \$43.8 billion USD; but by 1986 they had declined to $\$ 26.3$ billion USD. U.S. stockpiles of wheat, corn, and rice grew rapidly. By the mid-1980s, the American farm sector was in crisis due to overproduction and high farm debt, which led to farm closures. Export markets for American products that had been robust in the 1970s contracted as oil price shocks led to tighter monetary policy, higher interest rates, and weakened purchasing power. ${ }^{6}$ Thus, the United States was saddled with an expensive farm policy at a time of declining exports. Faced with a domestic farm problem, the U.S. government felt that freer agricultural trade would open new markets and help to alleviate farm surpluses that were driving down domestic prices. This situation served as the background to the Uruguay Round of negotiations. 
In September 1986 the eighth round of GATT negotiations began, called the Uruguay Round. The Soviet Union requested to join the negotiations but was denied permission. In 1990, the Soviet Union applied for observer status to GATT but was originally blocked by the United States. The United States subsequently relented following opposition to its stance from other countries. In May 1990 the Soviet Union was granted observer status to GATT, a move that represented the first step in integrating to the world trade system. Observer status allowed Soviet representatives to attend meetings but not to participate in decision-making or dispute resolution. ${ }^{7}$

After several years of negotiations and several failures, in 1994 the Uruguay Round Agreement on Agriculture (AoA) was signed, which focused on improving market access, domestic support, and export subsidies. The Uruguay Round Agreement came into effect in 1995 and improved access to foreign markets for food exporting countries by lowering tariffs and removing quantitative restrictions on imports. Countries agreed to convert quantitative restrictions to tariffs, to be followed by a reduction in tariffs. ${ }^{8}$ Developed countries would reduce their agricultural tariffs by an average of one-third over six years while developing countries would reduce their tariffs by an average of 25 percent over ten years. ${ }^{9}$ Under the AoA, domestic subsidies to agriculture were also scheduled for reduction. Developed countries were to reduce their domestic subsidies by 20 percent over six years while developing countries would reduce subsidies by 13 percent over ten years. ${ }^{10}$ Least developed countries were exempt from any reductions. Domestic subsidies were categorised into different boxes, representing the level of distortion that they caused in trade. Subsidies in the 'amber box' were considered highly tradedistorting and were to be reduced the most. 'Green box' subsidies were considered to have minimal trade-distorting effects and did not require reduction. 'Blue box' subsidies also did not require reductions and were not limited. Finally, the AoA required reductions in export subsidies, the purpose of which was to end agricultural dumping (selling below production cost). Developed countries would reduce their export subsidies by an average of one-third over six years while developing countries would reduce their subsidies by an average of 25 percent over ten years. ${ }^{11}$

Although the AoA represented progress in liberalising agricultural trade, Clapp notes that because the United States and European Union (hereafter EU) moved many of their subsidies into green and blue boxes, their level of subsidies increased in comparison to the 1980s. Moreover, as 
late as 1998 agricultural protection remained high and tariffs averaged 40 percent. Clapp argues that, 'loopholes in the agreement allowed United States and the EU to continue with many of the protectionist practices to which they had become accustomed. As such, the AoA has been criticized as reinforcing already unequal agricultural trade rules'. ${ }^{12}$ Davis adds that, 'nontariff barriers remained common in the agricultural sector long after they were eliminated for most industrial goods'. ${ }^{13}$ Ironically, developed countries raised their level of agricultural protectionism even as the size of the agricultural sector was shrinking in comparison to the rest of the economy.

Until the last two years of its existence, the Soviet Union was virtually a non-entity in Western international trade arrangements. Its primary trade, both agricultural and non-agricultural, was with fellow East bloc nations who comprised the Council for Mutual Economic Assistance (CMEA, sometimes referred to as Comecon, 1949-1991). This bloc of communist economies was not integrated with capitalist economies and instead opted for intra-bloc trade to the widest extent possible. Communist leaders wanted to protect their consumers from global food prices and their producers from Western competition. As a result, Soviet protectionism vis-à-vis Western nations was in line with Western protectionism as described above.

In 1993, Russia's post-Soviet government applied to join GATT, which in 1995 became the World Trade Organisation (WTO). Negotiations over Russia's entry to the WTO would continue for 18 years, cycling through periods of cooperation when membership seemed near and animosity. ${ }^{14}$ Negotiations over agriculture were particularly contentious. ${ }^{15}$ Finally, a breakthrough occurred in fall 2011 that led to a positive vote to allow Russia's membership. In July 2012 the State Duma ratified the agreement and in August 2012 Russia officially joined the WTO, the 156th country to do so at that time. Accession brought two major changes. First, Russia's membership to the WTO represented integration with the global trading system. Second, Russia's integration into the global institutional trading system brought obligations and responsibilities. ${ }^{16}$

Not long after Russia's WTO accession, however, the 2014 political crisis in Ukraine and Crimea led President Vladimir Putin to suspend some of Russia's commitments by invoking 'protection of national security', allowed by Article XXI in GATT. ${ }^{17}$ Since then, Russia has continued to communicate with the WTO concerning issues in food safety, photosanitary standards, and veterinary requirements. Broader trade obligations 
such as refraining from the use of import quotas or import bans have gone by the wayside. Russia also continues to use various forms of state assistance that may be considered market-distorting, for example, transportation subsidies for grain from point of origin to port. That said, it is useful to review briefly the set of obligations that Russia agreed to when it joined the WTO.

First, Russia's agricultural budget for 'trade-distorting support' was limited to no more than $\$ 9$ billion (USD) in 2012 and 2013, which dropped to $\$ 4.4$ billion by 2018 . Not limited are expenditures for research, disease control, infrastructure, food security, farm restructuring, and rural development, which are not considered trade distorting.

Second, the average tariff rate for agricultural products after full implementation was scheduled to decline from 13.2 to 10.8 percent. ${ }^{18}$ In comparison, the average tariff rate for manufactured goods dropped from 9.5 percent currently to 7.3 percent, so agriculture remained somewhat more protected but less so than in the past. For context, during 20002008 Russia's average tariff rate on imported food almost doubled from 10 to 18 percent, which is not especially high by global standards as many nations have much higher tariff rates, including the EU, but it did represent more, not less, protectionism. ${ }^{19}$ Thus, entry into the WTO was expected to bring a reduction in Russia's agricultural tariffs.

A third obligation was that one-third of tariff lines were to be reduced on the date of accession, with another one-quarter of tariffs to be reduced within three years. The longest implementation period was to be eight years for pork. Tariff rates for dairy products and cereals were to be reduced by about 5 percent; tariffs for oilseeds, fats, and oils were to decline by about 2 percent. ${ }^{20}$ Under the terms of accession, tariffs for agricultural products would decline by more but still be higher than for many other non-agricultural goods. Russia was allowed to continue to use tariff-rate quotas (TRQs) for beef, pork, and chicken. Russia's use of TRQs, which originated in 2003, was adjusted in 2012 following Russia's accession. According to the adjustment, the in-tariff quota for fresh and chilled beef was increased from 30 thousand tonnes to 33 thousand tonnes; the in-tariff quota for fresh and chilled pork was reduced from 472 thousand tonnes to 400 thousand tonnes; and the in-tariff quota for fresh and chilled poultry was raised from 330 thousand tonnes to 341 thousand tonnes. From 2013 through 2019 in-tariff quotas for these products were kept constant: $\mathbf{5 7 0}$ thousand tonnes for fresh, chilled, and frozen beef; 400 thousand tonnes for fresh, chilled, and frozen pork; and 
364 thousand tonnes for fresh, chilled, and frozen poultry. In compliance with its promises made to the WTO, starting in 2020 Russia's in-tariff quota for pork was abolished and all pork imports were subject to a 25 percent tariff. Previously, pork imports within the in-tariff quota were taxed at 0 percent and outside the quota at 65 percent. ${ }^{21}$ Whether linked to the ending of the TRQ or the rise in domestic pork production, pork imports fell in 2020 to a very low level (see Chapter 4). In late 2020, Russia proposed to the Eurasian Economic Union to replace its TRQ for beef with a flat tariff rate of 27.5 percent. If approved, the change would take effect in January 2022.

\section{Russia's Agricultural Trading Behaviour}

This section moves from the global trading institutions to Russia's actual trading behaviour over several time periods. The USSR was an irregular player in the international (Western dominated) agri-food trade system prior to the 1970s. The first significant Soviet foray into the international grain market followed poor harvests in 1963 and 1965. During 19641966 the Soviet Union was forced to make large grain purchases on the international food market for the first time since World War II. The 19641966 period was also the first time that Soviet grain imports exceeded grain exports since the early 1950s. ${ }^{22}$

The Soviet Union's entry into international food markets as a grain importer was driven by several factors: domestic production shortfalls; grain stock building policy; the need for feed grain for cattle; and livestock expansion plans. Soviet food imports were also influenced by weather anomalies during the 1960s-1980s. Arguably, aside from weather, the most important driver for grain imports was the degree to which domestic production could meet consumption needs. ${ }^{23}$ Starting in 1971, Soviet leaders decided to improve levels of food consumption and to increase livestock inventories which would lead to higher meat production. ${ }^{24}$ Henceforth, the so-called 'social contract' between regime and population was based on a commitment to produce more food and increase consumption during each successive Five-Year Plan. Specifically, Soviet leaders wanted to increase output in animal husbandry in order to meet rising consumer demand for meat, milk, cheese, and other animal-based protein. During several five-year plans the goal to increase meat consumption was successful, as annual per capita consumption rose from $47.5 \mathrm{~kg}$ in 1970 to $62.4 \mathrm{~kg}$ in $1986 .{ }^{25}$ These official statistics do not, of course, 
factor in the quality of production or the time that consumers expended to obtain meat which had an economic cost to productivity. The Soviet social contract based on a more diversified diet was mirrored in Eastern Europe. Deutsch links political stability in Eastern bloc countries with the need to improve food consumption via a 'food revolution', writing that 'rising consumer demands now form the most serious challenge that the socialist system has ever had to meet'. ${ }^{26}$

\section{Russia's Trading Behaviour in the i970s}

During the pre-1970s period, the USSR did not play a significant role in the international food system except during 1964-1966 due to exceptional circumstances when grain was imported from the West as noted above. During the 1970s, Russia's frequency of entrance into the global food market was periodic, its integration with global institutions was low, and its degree of involvement with the global food market was low. Soviet entry into the international food system was based on need until the early 1970s. Conversely, its protectionism was high.

The 1970s began with the USSR basically food self-sufficient. In 1970 the Soviet Union was actually a net grain exporter of more than 7 million metric tonnes (mmt). As previously noted, most of Soviet Russia's trade consisted of intra-bloc trade with CMEA nations. This occurrence was an outflow of the economic integration imposed by the Soviet Union on Eastern Europe during the 1950s and 1960s, and by the 1971 Comprehensive Program for Socialist Integration that stressed plan coordination, joint investment projects, and cooperation in long-term programmes. ${ }^{27}$ During the first half of the 1970s, trade with the West by CMEA nations accounted for only 30 percent of exports and 37 percent of imports. ${ }^{28}$

The positive food situation in the USSR changed rapidly as poor harvests occurred in 1971-1972, followed by another poor harvest in mid-decade (1975) and at the end of the decade (1979). Actual grain output during 1971-1975 fell significantly below planned levels, and the same was true for the 1976-1980 Five-Year Plan as well. ${ }^{29}$ As a result, the Soviet Union became a more significant participant in the global food system, although not on a regular basis. Beginning in 1972, the Soviet Union turned to the West for grain imports and particularly the United States (see Chapter 10). The Soviet Union became a 'burden' on the world food system. ${ }^{30}$ As a further irritant, Robert Paarlberg argues that the Soviets 'used its access to western food markets as more than a 
means to compensate for domestic production shortfall' by re-exporting imported American grain at a higher price. ${ }^{31}$

In 1979, the Soviet Union experienced another poor harvest. The volume of grain available for domestic trade was down about $30 \mathrm{mmt}$ compared to 1978 , including a decline of more than $20 \mathrm{mmt}$ of wheat. ${ }^{32}$ The USSR again turned to the West, and particularly the United States, to purchase grain. But that effort was stymied following the Soviet Union's December 1979 invasion of Afghanistan after which U.S. President Jimmy Carter imposed an embargo beginning in January 1980 on $17 \mathrm{mmt}$ of wheat sales that had been sold to the Soviet Union. The embargo lasted into April 1981. The Soviet Union started the decade as an irregular and mostly insignificant player in the international food system, but during the 1970s it became a consistent purchaser of Western grain, which means that its entrance into the global food market became more frequent and its degree of involvement with the global food market rose.

\section{Russia's Trading BeHaviour in THE i98OS}

During the 1980s, Russia's frequency of entrance into the global food market was high, its protectionism was high, and its degree of involvement with the global food market was high as a consistent grain importer. Its integration with global institutions remained low.

In the 1980s the USSR became a regular participant in the international food system by importing grain due to domestic shortfalls. The 1980s started badly, beginning with three consecutive years of poor harvests, 1980-1982. By 1982, the Soviet Union had a net agricultural trade deficit of $\$ 18$ billion and had net grain imports of $45 \mathrm{mmt}$, a very different situation from just a decade earlier. Another very poor harvest came in 1984. During 1980-1985 grain output in the Soviet Union averaged about $182 \mathrm{mmt}$, far short of the $200 \mathrm{mmt}$ that state planners had anticipated. To be clear, domestic grain production was sufficient to provide the population with bread and grain products and Western analysts recognised that hunger was not a problem in the USSR. ${ }^{33}$ Poor harvests created feed grain deficiencies that affected livestock herds that trickled down to affect meat and milk production. The Kremlin's plan to expand livestock herds stalled.

The Soviet Union transformed from a periodic participant in the international food system in the 1970s into a regular buyer of grain during 
the 1980s who impacted the world food system. In the early 1980s, Western economists warned that Soviet demand for imported grain could 'create disruption in world grain trade with serious consequences for both grain-exporting and grain-deficit countries'. ${ }^{34}$ During 1976-1980, the Soviet Union imported an average of $19.9 \mathrm{mmt}$ of grain per year. In the 1981-1985 period, however, average annual grain imports rose to over $40 \mathrm{mmt}$, of which $12.4 \mathrm{mmt}$ were purchased from the United States. ${ }^{35}$ The value of Soviet grain imports from the West averaged \$10 billion USD per year during 1981-1984 when hard currency reserves were declining. Moreover, the Soviet Union also became a buyer of meat, fruit, vegetables, vegetable oil, and sugar on the international market. ${ }^{36}$ The Soviet Union's largest impact on the international food market, however, remained its grain imports.

The final Soviet leader, Mikhail Gorbachev (1985-1991), frequently spoke about far-reaching reforms in agriculture. He had made his reputation for modest agrarian reforms as First Secretary in Stavropol' krai in the 1970s. After he was brought to Moscow in 1978, he became Party Secretary for agriculture in November 1978, a position for which he was eminently qualified, and he remained in the position for several years (1978-1984). As the secretary in charge of agriculture, he played a large role in drafting the 1982 Food Programme. As General Secretary of the Communist party, Gorbachev targeted agriculture for reform, although space limitations prevent a full discussion of those reforms. ${ }^{37}$ Gorbachev first tried to implement some of the goals of the 1982 Food Programme-improving the capital stock of farm machinery and repair facilities, improving storage and transportation, improving rural housing, and upgrading food processing and packaging. ${ }^{38}$ After 1987, Gorbachev moved beyond the Food Programme to embrace farm self-financing, farm autonomy and incentives, land leasing, and encouraging a private (nonstate) sector. In 1987 foreign trade was partially liberalised although the USSR did not turn into a free trade country. During Gorbachev's early years in power, 1985-1987, the Soviet Union remained highly food protectionist except when needed. After 1988, the Soviet economy opened up and foreign companies entered the Soviet food market in food retailing and restaurants, including the opening of the first McDonald's restaurant in Moscow in $1990 .^{39}$

Despite the fact that there was a short-term rise in food consumption, Gorbachev's reforms did not bring farm autonomy and food losses remained high: as much as 30 percent of the harvest and 50 percent 
for potatoes and vegetables. ${ }^{40}$ The Stalinist procurement system that had existed since the 1930s crumbled in 1990 and 1991 and the prodnalog (food tax) proved ineffective for obtaining food to feed the cities and maintain livestock. ${ }^{41}$ As a result, grain imports from the West continued to be high. Despite favourable harvests of $211 \mathrm{mmt}$ in 1989 and $235 \mathrm{mmt}$ in 1990, the USSR imported nearly $40 \mathrm{mmt}$ of grain in 1989 and $26 \mathrm{mmt}$ in 1990. In 1991, the last year of the Soviet Union's existence, the harvest was less than $173 \mathrm{mmt}$ and it imported $38 \mathrm{mmt}$ of grain. ${ }^{42}$ Gorbachev's agrarian reforms did little to reduce reliance on Western grain, which meant that entrance into the global food market remained frequent and its degree of involvement with the global food market remained high. Its agricultural trade protectionism transitioned from high to low by the end of the decade.

\section{Russia's Trading BEHAVIOUR IN THE I99OS}

In the 1990s, Russia's frequency of entrance into the global food market was high and its degree of involvement in the global food market was high as the value of imports rose significantly. Post-Soviet protectionism was low during much of the decade although that started to change in mid-decade. The degree of integration with Western global institutions remained low as Russia remained outside of GATT/WTO.

As the country transitioned from a command to a market economy during the 1990s, Russia was a regular participant in the international food trade system as an importer due to the steep decline in its agricultural production. Large farm enterprises traditionally fed the nation, whereas food production from household gardens tended to be consumed by the household, in other words, locally. An index for 1994 estimated agricultural output by agricultural enterprises (large farms) at 57 percent of their 1990 level. ${ }^{43}$ To compensate for falling domestic production by large farms, Russia turned to food imports. Calculated in U.S. dollars, the value of Russia's food imports rose from \$5.6 billion USD in 1993 to $\$ 13.3$ billion USD in 1997 before declining in 1998 and 1999 following the financial collapse and devaluation of the ruble that made foreign food very expensive. It is worth noting that the value of food imports exceeded by many times the value of domestic food production. The 1990s witnessed an increase in food imports from the West, which replaced former republics as Russia's primary food trading partner. Up to 
1998, the dollar value of food imports from states not in the Commonwealth of Independent States (CIS) exceeded the dollar value of food imports from CIS members by a factor of two or three, depending on the year. $^{44}$

The increase in the value of Russia's food imports accompanied the liberalisation of the economy and foreign trade after 1992. Although still not a member of GATT, the early post-Soviet years witnessed a lowering of Soviet-era barriers and further opening the Russian economy in anticipation of early membership in the WTO. As a result, foreign foodstuffs both raw and processed flooded Russia's marketplace. Within the context of a rising value of food imports, Russia changed from a large importer of grain early in the decade (more than $15 \mathrm{mmt}$ per year during 19901992), ${ }^{45}$ to a large meat importer by mid-decade, driven by a significant drop in domestic livestock herds. The percentage decline in the number of pigs, beef cattle, and milk cows during the first five years of market reform in the 1990s exceeded the losses during the first five years of Stalin's collectivisation. The decline in livestock herds reflected farm adaptation to new economic conditions: a range of state subsidies disappeared, price increases for domestic feed grain, fuel, and other inputs exceeded farmgate prices. As a consequence, large cities were importing upwards of 70-80 percent of their meat by 1995-1996. ${ }^{46}$

Russia had poor harvests throughout the decade. The first year as a non-communist state started with a good harvest of nearly $107 \mathrm{mmt}$ in 1992. During 1995-1996, however, its grain harvest averaged $66.3 \mathrm{mmt}$ and in 1998-1999 it averaged of just $51.2 \mathrm{mmt}$ per year. Nonetheless, grain imports averaged just $3.74 \mathrm{mmt}$ for 1995-1996 and $3.78 \mathrm{mmt}$ for 1998-1999, far below the levels of the 1980s. The precipitous decrease in the size of livestock herds was one reason why grain consumption plummeted and there was less need for foreign feed grain, as explained by the Lieferts in Chapter 2. In addition, consumers' food consumption patterns changed. As retail food subsidies from the state disappeared after 1992, for most Russian consumers the primary problem during the 1990s was the price of food, not availability. ${ }^{47}$ In the grips of a major recession, consumers ate less beef, which put downward pressure on farm incentives to maintain large herds. ${ }^{48}$ By 1996-1997 Russian consumers substituted cheap imported poultry for domestic beef, similar to how American consumers turned to chicken during the early 1930s when up to one-half of households had no regular income during the Great Depression. The availability of cheap starches and carbohydrates meant that even 
with high food inflation and mass poverty, there was no mass hunger even as average caloric intake decreased. ${ }^{49}$

Russia's financial crisis in 1998 led to three occurrences that affected its food imports. First, with the devaluation of the ruble, imported food became very expensive and thus Russian consumers shifted to domestic products. As a result, the dollar value of food imports fell from $\$ 13.3$ billion USD in 1997 to $\$ 7.3$ billion USD in 2000. Second, Russian food processors and manufacturers adapted quickly to capitalise on their price advantage and created attractive packaging that mirrored Western brands. Third, Russia's trade policy became more protectionist.

The origins of increased trade protectionism pre-dated Russia's August 1998 financial crisis. By 1996-1997 conservative voices in society and the government were raising alarms about threats to national food security. In December 1997, President Boris Yeltsin approved a document titled 'Conception of the National Security of the Russian Federation', which stated that dependence on food imports and Russia's integration into the world market was not beneficial. Simultaneously, conservative and nationalist groups within Russia complained about the loss of food independence. ${ }^{50}$ In April 1998, the law 'On Measures of Protection of Russian Economic Interests in Foreign Trade' was signed that identified poultry, vegetable oil, and meat for protection through an increase in tariffs. ${ }^{51}$ In June 1998, a 5 percent increase in tariffs for all food imports was enacted. At this time, Russian leaders were engaged in a delicate balancing act, wanting to protect domestic producers while simultaneously avoiding a large increase in the cost of food to the average family budget, which already was quite high; and in 1998 the Yeltsin administration still held out hope to join the WTO by the end of the year and thus did not want to go too far in protectionist measures.

Following Russia's financial crisis in August 1998, then-Minister of Agriculture Viktor Semenov (April 1998-May 1999) called for a 'new course' in agrarian policy that rested on increased state regulation of the agro-industrial complex and defence of Russia's domestic food market. In particular, Semenov noted that export subsidies in the European Union undercut Russian producers, thus 'easily conquering' Russia's food market. ${ }^{52}$ Aleksei Gordeev, who became Minister of Agriculture in August 1999 (to March 2009), was explicit that his 'new agrarian policy' would emphasise strengthening the role of the government in regulating Russia's food market. He also specified that tariff-custom policy would 
create conditions whereby domestic producers could effectively compete with food imports. ${ }^{53}$

\section{Russia's Trading BeHAVIOUR IN THE 2000-2OI3 PERIOD}

During the 2000-2013 period, Russia's frequency of entrance into the global food market was high and its degree of involvement in the global food market was high as the value of food imports and exports rose significantly. Russia's degree of protectionism remained relatively low. The degree of integration was transitional as Russia finally became a member of the WTO in 2012.

Russia remained a consistent participant in the international food trade system as a food importer. The value of Russia's food imports grew substantially as a result of economic recovery, a significant increase in real per capita income, and a strengthening in the ruble that made imports cheaper. Russia's agricultural imports increased from \$7.3 billion USD in 2000 to over $\$ 35$ billion USD in 2008. After a brief decline in food imports in 2009 due to the global financial crisis (Russia's GDP fell by almost 9 percent), the value of food imports began to rise again in 2010 and eventually reached its post-Soviet peak of $\$ 43.2$ billion USD in 2013. Similar to the 1990s, the largest value of food imports consisted of meat and animal husbandry, not grain, as explained by the Lieferts in Chapter 2. Other main imports included highly processed foods, fruits, and vegetables. During the first decade of the 2000s, Russia became the second largest agricultural importer among emerging markets, trailing only China. It is conceivable that the value of Russia's food imports would have continued to rise had the 2014 Ukrainian crisis not occurred that led to a ban on agri-food imports from major Western nations.

Russia's participation in the international food trade system was also fuelled by a rise in its food exports. The value of Russia's agricultural exports grew from $\$ 1.62$ billion USD in 2000 to $\$ 10$ billion USD in 2009 before declining in 2010. Russia's food exports then rose to $\$ 12$ billion USD in 2011 and reached their pre-Ukrainian crisis high of \$18.9 billion USD in 2014. Most of the export growth came from grain (mainly wheat and barley). Grain exports rose from $1.3 \mathrm{mmt}$ in the $2000 / 2001$ agricultural year to $21.8 \mathrm{mmt}$ in the $2009 / 10$ agricultural year before declining in 2010/2011 due to a drought and a subsequent ban on grain exports from August 2010 to July 2011. One the export ban ended, grain 
exports started to increase again, reaching $22.4 \mathrm{mmt}$ in the 2012/2013 agricultural year. Grain exports generated the most foreign trade revenue among Russia's food exports. Expressed in dollar value, however, the overall impact of Russia's exports on the world food system was low. During 2000-2009, the value for global exports of food commodities averaged $\$ 522$ billion USD per year. ${ }^{54}$ The dollar of Russia's food exports during the same period averaged just $\$ 5.14$ billion USD.

Foreign food trade protectionism remained low during this time period. In 2003 Russia introduced tariff-rate quotas on beef, poultry, and pork that offered some protection to domestic producers. The Putin administration walked a fine line: on the one hand it wanted to protect domestic large farm enterprises from foreign competition until such time that they could compete effectively, and it wanted to help them recover financially. On the other hand, it wanted to meet rising consumer demand for food and therefore the volume of meat imports continued to climb. If cheaper food imports helped to limit the amount an average household spent on food, all the better.

Government policy began to emphasise food security in 2008 when the combination of high food imports and the dramatic rise in global commodity prices sparked fear of contagion. In 2008, a Food Security Doctrine was drafted and circulated for commentary; it was signed into force in January 2010 by former President Dmitrii Medvedev, the importance of which was to quantify what percentage of different foodstuffs Russia should produce for itself in order to be food secure. Until 2014, Russia's Food Security Doctrine did not translate into higher trade barriers or an increase in food trade protectionism aside from what already existed.

Russia's integration with global food trade institutions transitioned from low to high as Russia finally became a member of the WTO in 2012 after being an observer to the WTO for many years. The debates over whether to integrate with the world trading system appeared to be over. ${ }^{55}$ At the time Russia entered the WTO, most of its food trade was with Western nations. In 2000, for example, 72 percent of Russia's food imports came with nations that were not former Soviet republics in the Commonwealth of Independent States (CIS), as did 56 percent of its food exports. Over time, trade with non-CIS nations increased. In 2013, the last full year before the Ukrainian crisis in 2014 and Russia's subsequent food embargo in August 2014, food trade with non-CIS nations 
accounted for 85 percent of Russia's food imports and 70 percent of its exports. ${ }^{56}$

After the Ukrainian crisis and the first rounds of Western sanctions in 2014, Putin invoked the protection of national security clause in the WTO to relieve Russia from some of its commitments, for instance, not to introduce food bans or treating trading partners differently. Russia continues adhere to other obligations. In 2017 import duties on sunflower oil, water, and cigars were reduced in accordance with commitments made to the WTO. As noted before, in 2020 Russia ended its tariff-rate quotas on pork, replaced by a flat tariff of 25 percent. Whether coincidental to the changed tariff rate or not, Russia's pork imports fell in 2020, attributed to rising investment in the sector, increased output, and the attraction of export possibilities.

\section{Russia's Trading BEHAVIOUR SINCE 2014}

Since 2014, two contradictory impulses in Russia's agri-food trade policy have become discernible. The first impulse is a strong emphasis on food security, import substitution, and food self-sufficiency (see Chapter 4). As Clapp reminds us, self-sufficiency means to produce enough to meet one's own needs, and thus food self-sufficiency is concerned with the origin of food. ${ }^{57}$ Self-sufficiency policy implies not just protectionism but a withdrawal from international markets in terms of food imports. ${ }^{58}$ The second impulse, which contradicts the first, is an emphasis on expanding food trade, opening new markets, and increasing food exports. Despite a food self-sufficiency policy, Russia has not withdrawn from international food markets, and although the dollar value of its food imports is down from the pre-2014 period, Russia remains a large importer of food. In this respect, Russia's policy of self-sufficiency is not exactly what the literature would assume is true. Further, although Russia's food security policy has economic implications, it should be understood as a political variable that is used in tandem with food trade as an instrument of foreign policy, and as a prop for nationalism. What this means is that Russian leaders definition of 'success' in food security is very narrow, referring mainly to the production of several basic commodities. But if the view of food security is expanded just a bit, it is obvious that the Russian version of food security, i.e., protectionism and lessened dependence on imports, is far from reality. In this respect, one may point to high percentages of seeds that are 
imported; high percentages of farm imported farm machinery and equipment; high percentages of imported pedigree livestock; and a substantial presence and market share by foreign agri-firms in food processing and food retailing. One might even include the erosion of human capital in rural areas, a result of outmigration, as an aspect of food security. ${ }^{59}$ Thus, a narrow fixation on certain commodity production, therefore, does not offer a complete or necessarily accurate view of Russia's food security.

Turning to the four variables that frame the analysis, since 2014 Russia's frequency of entrance into the global food market has been high and its degree of involvement in the global food market is high. Russia regularly enters the global food market as both a food importer and exporter, both of which are valued in the tens of billions of dollars annually. Agri-food trade protectionism became variegated as it transitioned from low protectionist to selectively high towards Western nations while remaining more open to non-Western nations. The degree of integration with Western institutions transitioned from high following entry to the WTO in 2012 to low starting in 2014 and continuing thereafter.

The year 2014 was a watershed year for Russia's role in the international food trade system. The origins of change in Russia's role in international food trade were found in the Ukrainian crisis that witnessed the removal of Ukrainian President Viktor Yanukovych in February 2014, followed by Russia's military involvement in eastern Ukraine and annexation of Crimea in March 2014. Subsequently, Western sanctions were placed on Russia in March and July 2014, and Russia's countersanctions - a food embargo against the West-were announced in August 2014. Russia's countersanctions, often referred to as the food embargo, banned most agri-food imports from the United States, the European Union, Canada, Norway, and Australia from 7 August. The ban has been extended several times since then and currently runs to the end of 2022. In 2015, four other nations were added to the banned list, and in 2016 Ukraine was added. Since 2014, four discontinuities with previous agri-food trade patterns have occurred.

The first discontinuity from the pre-2014 period is a reversal in the upward trend in the dollar value of Russia's food imports. Russia's food imports rose from $\$ 30$ billion USD in 2009 to over \$43 billion USD in 2013. Following the introduction of Russia's food embargo in August 2014 against Western nations, its food imports fell to $\$ 26.5$ billion in 2015 and then to a low of $\$ 25$ billion USD in 2016 before starting to rise somewhat in subsequent years, but remaining far below the pre-embargo 
level. In 2020, the value of food imports was just over \$29 billion USD. As noted above, the decline in the value of Russia's food imports was facilitated by policies of import substitution and food self-sufficiency, both of which were actively pursued by the Kremlin (see Chapter 4).

A second discontinuity is a significant rise in the volume and value of food exports, a departure from many years of moderate food exports. The rise in exports is due to a confluence of factors, including favourable weather, state financial assistance that promotes higher grain production, protectionism from competition, and favourable farming practices such as re-mechanisation, digitalisation, and increases in yield per hectare. Russia's wheat exports since the 2014/2015 agricultural year and continuing through the 2019/2020 agricultural year averaged more than 37 mmt. From 2014/2015 through the 2019/2020 agricultural year, Russia led the world in volume of wheat exports in four of the six agricultural years, and ranked second in the other two agricultural seasons. By volume, in the 2016/2017 agriculture year Russia's wheat exports accounted for 14 percent of global wheat trade; in the $2017 / 2018$ agricultural year, Russia's wheat exports accounted for 18 percent of global wheat trade; 19 percent in the 2018/2019 agricultural year; and 18 percent in the $2019 / 2020$ agricultural year. ${ }^{60}$

In 2020, grain exports generated approximately one-third of Russia's total food export revenue ( $\$ 9.7$ billion of $\$ 28.9$ billion USD), and wheat in particular accounted for more than any other agri-food commodity. ${ }^{61}$ In 2020, other main food exports consist of fish and seafood (18 percent of total), fats and oils (16 percent of total), and processed and manufactured foods (14 percent of total). Although Russia will remain a major grain exporter, it is necessary to note in passing that political food security remains an important variable. During the second half of the 2019/2020 agricultural year the government introduced an export quota of $7 \mathrm{mmt}$ to the end of June when a new agricultural year would begin (on I July). In reality, the quota was reached prior to the 30 June deadline. Although the quota did not appear to directly reduce grain exports, the existence of the quota affected the willingness of traders to enter into contracts. The purpose of the quota was to ensure that too much grain was not exported, fuelling inflation or causing domestic shortages. For the 2020/2021 agricultural year, the government introduced another export quota of 17.5 mmt 15 February 2021 to 30 June 2021, plus an export tariff. Starting 15 February, the tariff was 25 euro per tonne which doubled to 50 euro per tonne on 1 March. From 2 June 2021, a flexible tariff was used for wheat, 
corn, and barley sold outside the Eurasian Economic Union (EAEU), equal to 70 percent of the difference between the contract price and the base price of $\$ 200$ per tonne for wheat and $\$ 185$ for corn and barley. ${ }^{62}$

A third discontinuity is a partial withdrawal from integration with major Western nations, at least as far was food imports into Russia are concerned, although Russia continues to export to member states of the European Union. Russia has not withdrawn from the WTO, although some voices within Russia have called for doing so. Further, as early as 2015 the United States Trade Representative noted in its annual report about Russia's compliance to its WTO commitments that Russian standards for tetracycline, ractopamine, and other hormones in pork and beef were more stringent than accepted levels. The June 2015 report concluded that 'the United States has become increasingly concerned that Russia may be moving away from the core WTO principle of trade liberalization'. ${ }^{63}$ Subsequent reports continued to express concern over Russia's standards, notification of risk assessment, and implementation. The 2018 report, for example, noted that, 'although Russia has put in place the legal framework to allow it to comply with its WTO commitments, its implementation of these commitments remains problematic....Russia does not appear to have implemented fully its commitments to base measurements on international standards, or, where it applies a more stringent standards, to provide a science-based, objectsive risk assessment' ${ }^{64}$ In other words, Russia became increasingly willing to use non-tariff barriers such as sanitation requirements to restrict food imports from the West.

A fourth discontinuity flows from the third and concerns the expansion of trade relations with non-Western partners. Russia has changed its main food trading partners, substituting China and Southeast Asia, the Middle East, and South America for the EU and United States. The discontinuity is seen by the fact that up to 2014 the EU was Russia's primary partner in agricultural trade. Ironically, while most agricultural imports from the EU are banned, the EU remains an important market for Russia's food exports. In 2020, the EU ranked second after China in dollar value of Russia's agri-food exports, accounting for about 11 percent. ${ }^{65}$ Following the events in Ukraine in 2014, Russia turned elsewhere to substitute for its lost partner in the EU (see Chapters 5 And 7).

Furthermore, the EAEU, which came into being in January 2015, represents Moscow's efforts to create a regional trade bloc with nonWestern nations. Other chapters explore agri-food trade within the EAEU in more detail, but here suffice it to say that since its inception the EAEU 
has expanded its trading network. In May 2018 China signed a trade agreement with the EAEU that has been touted as a free trade agreement but in reality seems to be something less than that as explained in Chapter 8. In May 2018, Iran signed a provisional free trade agreement with the EAEU that covers a limited number of goods, including agricultural products. The provisional agreement is to last for three years and paves the way to full free trade. In December 2018 the EAEU and Iran established free trade zones. In October 2019, the EAEU and Serbia signed a free trade zone agreement for cheese and alcohol, building on the previous preferential trade agreement. ${ }^{66}$ The EAEU had previously agreed to free trade with Vietnam in December 2016, and trade between Russia and Vietnam is explored in Chapter 6. The point is that Russia is using the EAEU to pivot its food trade away from Western nations.

The opening to non-Western trade partners is further witnessed by Russia's bilateral memoranda of understanding (MoU) or statements of cooperation in agriculture with India, Morocco, China, Syria, Mongolia, Japan, and Saudi Arabia during 2017-2019, to name just a few. Egypt, Iran, Bangladesh, and Turkey remain main purchasers of Russian wheat. Food trade with China very likely will increase as Russia's exporters attempt to capture market share lost by American farmers due to the trade war started by President Donald Trump. Russia's food exporters are also eyeing markets in Vietnam and other Southeast Asian nations and the Middle East as discussed in subsequent chapters. In addition to those regions, agricultural trade has expanded with South America since 2014. In particular, Russia became the largest importer of Brazilian meat. Chile has increased its exports of poultry, pork, fish, vegetables, and fruits to Russia. Uruguay also increased meat exports to Russia.

\section{OUTLOOK}

The future outlook for Russia's agri-food trade behaviour is summarised according to the four variables that comprise the analytical framework. The frequency of Russia's entrance into the global food market is likely to remain high as an annual importer and exporter. The Russia's structure of demand for food that suggests an impending large decrease in food imports. Further, Russia's food export ambitions commit the country to continue as a significant food exporter on an annual basis. Russia intends to remain an active participant in global food trade as evidenced by the adoption of an export programme in 2016, followed by the adoption 
of a national project on food exports in late 2018. The existence of an analytical centre within the Ministry of Agriculture facilitates Russia's food exports by training personnel in contracts and negotiations and providing consultation and legal services to exporting companies. The export project received more than R38 billion in 2019 and is scheduled to receive more than R400 billion during 2019-2024. ${ }^{67}$ Under the auspices of the export project, the Ministry of Agriculture is opening attaché offices abroad to establish trade ties in new markets. Russia's role as a food exporter is likely to expand.

Agricultural protectionism is likely to remain selectively high, which is to say that there is no end in sight to Russia's countersanctions against the West. Russia's domestic agri-food producers are pleased with the government's protectionism and favour its continuation. The government likes agricultural protectionism because it helps domestic producers and processors whose higher profitability leads to more tax revenue for regional budgets and the federal government. The government also appreciates the prestige that comes from being a large wheat exporter.

The degree of integration with Western trade institutions is likely to remain low. As noted above, the trend is for less cooperation with the WTO. Instead, Russia has pivoted to Asia, the Middle East, and other non-Western countries. Engagement with other BRICS nations, the EAEU, and the Shanghai Cooperation Organization (SCO), as well as bilateral trade ties has replaced most food imports from the EU. So far, the pivot has worked well and thus Russia shows little motivation to revert back to ties with the West which would make Russia vulnerable to the whims of Western policy again.

Russia's degree of involvement with the global food market is likely to remain high. Russia will continue to import food valued in the tens of billions of dollars annually. As an exporter, Russia is likely to account for a significant portion of global grain trade. A major effort is being made to increase the export of processed and manufactured food products, not just raw commodities. Further, Russia's agricultural sector is generally considered to be a winner during climate change as growing seasons in northern latitutes lengthen. Around the world, water tables are depleted, but Russia has an ample supply of water. In many regions of the world, land is leached of its nutrients, but Russia has tens of millions of unused hectares of agricultural land. Russia is already increasing the cultivation of previously unused or abandoned agricultural land and expects to bring millions of hectares into production by 2025 . 
Finally, a few words about the impact of the COVID-19 pandemic on food exports. The pandemic created uncertainty for lives and livelihoods around the world, leading to higher unemployment, loss of income, the closure of businesses including restaurants, and disruptions in supply chains. The economic effects, which were initially quite severe-trade turnover in Russia decreased to 35-45 percent in April 2020 and by at least 60 percent at restaurants and cafes-may be shortlived as people get vaccinated and businesses rebound. ${ }^{68}$ Through it all, Russia's agricultural sector performed well, with the second largest harvest in the post-Soviet period at $133 \mathrm{mmt}$ of grain after cleaning. Russia's infrastructure for policy as a food exporting state remains strong: high ambition to be a global food power and to benefit from the leverage that accrues from that position; an active state that promotes food exports; and strong political commitment to increase global influence and status. Those factors, combined with a weak ruble, led Rossel'khozbank to predict that Russia's role in the world food system will become more significant despite myriad obstacles. ${ }^{69}$

\section{Notes}

1. Stephen K. Wegren with Alexander Nikulin and Irina Trotsuk, Russia's Food Revolution: The Transformation of the Food System (London and New York: Routledge Publishers, 2021).

2. Craig VanGrasstek, Trade and American Leadership: The Paradoxes of Power and Wealth from Alexander Hamilton to Donald Trump (Cambridge: Cambridge University Press, 2019), 289.

3. Jane M. Porter and Douglas E. Bowers, 'A Short History of U.S. Agricultural Trade Negotiations,' Staff Report no. AGES 89-23 (Washington, DC: Economic Research Service, 1989), 12-14.

4. Michael Reed, International Trade in Agricultural Products (Scotts Valley, CA: CreateSpace Independent Publishing, 2016), 169.

5. Jennifer Clapp, Food, 2nd edition (Cambridge: Polity Press, 2016), 6970 .

6. Porter and Bowers, 'A Short History of U.S. Agricultural Trade Negotiations', 18.

7. Burton Bollag, 'Soviet Union Becomes Observer in Trade Body', The New York Times, 17 May 1990. https://www.nytimes.com/1990/05/17/ business/soviet-union-becomes-observer-in-trade-body.html. Accessed 3 February 2020.

8. Reed, International Trade in Agricultural Products, 174.

9. Clapp, Food, 70. 
10. Ibid., 71 .

11. Ibid., 72 .

12. Ibid., 75-76.

13. Christina L. Davis, Food Fights Over Free Trade: How International Institutions Promote Agricultural Trade Liberalization (Princeton: Princeton University Press, 2003), 5.

14. William H. Cooper, 'Russia's Accession to the WTO and Implications for the United States', Congressional Research Service Report R42085 (15 June 2012), 3-5.

15. Stephen K. Wegren, 'Russian Agriculture and the WTO', Problems of PostCommunism 54, no. 4 (2007): 46-59.

16. This text draws from Stephen K. Wegren, 'The Impact of WTO Accession on Russian Agriculture', Post-Soviet Affairs 28 no. 3 (2012): 296-318.

17. Merlinda D. Ingco and John D. Nash, eds., Agriculture and the WTO: Creating a System for Development (Washington. DC: The World Bank, 2004), 29.

18. Olga Liefert, William Liefert, and Eric Luebehusen, 'Rising Grain Exports by the Formers Soviet Union Region', Economic Research Service Report WHS-13A-01 (February 2013), 16. https://www.ers.usda.gov/ webdocs/publications/39804/34899_whs13a01.pdf?v=0. Accessed 14 February 2020.

19. William Liefert, Olga Liefert, and Matthew Shane, 'Russia's Growing Agricultural Imports: Causes and Outlook', Economic Research Service Report WRS-09-04 (May 2009), 12. https://www.ers.usda. gov/webdocs/publications/40471/9481_wrs0904_1_.pdf?v=0. Accessed 9 February 2020.

20. Cooper, 'Russia's Accession to the WTO and Implications for the United States', 6.

21. IKAR, 'RF s l Ianvaria zamenila kvoti na import svininy poshlinoi, vypolniv vse obiazatel'stva pered VTO', 9 January 2020. https://agr ovesti.net/news/indst/rf-s-1-yanvarya-zamenila-kvotu-na-import-svininyposhlinoj-vypolniv-vse-obyazatelstva-pered-vto.html. Accessed 9 January 2020.

22. Alex Nove, 'Soviet grain: Problems and Prospects', Food Policy 1, no. 1 (November 1975): 34.

23. Edward C. Cook, 'Have the Soviets Turned the Corner on Grain Imports?' Food Policy 12, no. 2 (May 1987): 116-122. This position was not universally shared and Western economists debated other drivers of grain import policy, pointing to adequate reserves of foreign currency to purchase grain; the role of the planning system; and international grain prices. See Padma Desai, 'Soviet Grain and Wheat Import Demands in 1981-1985', American Journal of Agricultural Economics 64, no. 2 (May 1982): 312-322; George Allen, 'USSR Grain Imports: Past and Future', 
Food Policy 12, no. 2 (May 1987): 90-93; and C. T. Ennew, 'A Model of Import Demand for Grain in the Soviet Union', Food Policy 12, no. 2 (May 1987): 106-115.

24. Allen, 'USSR Grain imports: Past and Future', 91.

25. Goskomstat SSSR, Narodnoe khoziaistvo SSSS za 70 let (Moscow: Finansy i statistika, 1987), 470.

26. Robert Deutsch, The Food Revolution in the Soviet Union and Eastern Europe (Boulder: Westview Press, 1986), 5-6.

27. Paul Marer, 'The Political Economy of Soviet Relations with Eastern Europe', in Soviet Policy in Eastern Europe, ed. Sarah Meiklejohn Terry (New Haven: Yale University Press, 1984), 160-62.

28. Benedykt Askanas, Halina Askanas, Friedrich Levcik, and Michel Vale, 'The Foreign Trade of the CMEA Countries in the Second Half of the Seventies', Eastern European Economics 17, no. 3 (Spring 1979): 78.

29. D. Gale Johnson and Karen McConnell Brooks, Prospects for Soviet Agriculture in the 1980s (Bloomington: Indiana University Press, 1983), 15-16.

30. Paarlberg argues that from the early 1960s to the early 1970s the USSR increased its net grain imports by 18 million tonnes, more than Japan and the European Community who were the largest buyers of American grain at that time. Robert L. Paarlberg, 'The Soviet Burden on the World Food System: Challenge and Response', Food Policy 1, no. 5 (November 1976): 393.

31. Ibid.

32. Tsentral'noe statisticheskoe upravlenie SSSR, Narodnoe khoziaistvo SSSR $v$ 1980 g. (Moscow: Finansy i statistika, 1981), 207.

33. Karl-Eugen Wadekin, 'Soviet Agriculture's Dependence on the West', Foreign Affairs 60, no. 4 (Spring 1982).

34. Desai, 'Soviet Grain and Wheat Import Demands in 1981-1985', 312.

35. Author's calculations from data in Abram S. Becker, U.S.-Soviet Trade in the 1980s, Rand Note N-2682RC (Santa Monica: Rand Corporation, 1987), 5. https://www.rand.org/content/dam/rand/pubs/notes/ 2009/N2682.pdf. Accessed 1 February 2020.

36. Stephen K. Wegren, Russia's Food Policies and Globalization (Lanham: Lexington Books, 2005), 48; and Directorate of Intelligence, CIA, 'USSR: The Food Supply Situation'.

37. See Karl-Eugen Wadekin, 'Agriculture', in The Soviet Union under Gorbachev, ed. Martin McCauley (New York: St. Martin's Press, 1987), 118-34.

38. Penelope Doolittle and Margaret Hughes, 'Gorbachev's Agricultural Policy: Building on the Brezhnev Food Program', in Gorbachev's Economic Plans, vol. 2. Study Papers Submitted to the Joint Economic Committee of the Congress of the United States, Joint Economic Committee, 100th 
Congress, 1st session (Washington, DC: Government Printing Office, 1987), 30-33.

39. For a summary of the entrance of Western fast food restaurants into Russia in the late Gorbachev period, see Stephen K. Wegren, Alexander Nikulin and Irina Trotsuk, Food Policy and Food Security: Putting Food on the Russian Table (Lanham, MD and London, UK: Lexington Books, 2018), 23-24.

40. William Liefert, 'The Food Problem in the Republics of the Former Soviet Union', in The 'Farmer Threat': The Political Economy of Agrarian Reform in Post-Soviet Russia, ed. Don Van Atta (Boulder, CO: Westview, 1993), 28.

41. See Werner Hahn, 'The Farms' Revolt and Grain Shortages in 1991', in The 'Farmer Threat': The Political Economy of Agrarian Reform in Post-Soviet Russia, ed. Don Van Atta (Boulder, CO: Westview, 1993), 43-54.

42. World Bank, Food and Agricultural Policy Reforms in the Former USSR: An Agenda for the Transition (Washington, DC: The World Bank, 1993), Table 4.5 on p. 188.

43. Goskomstat Rossii, Rossiiskii statisticheskii ezhegodnik 1995 (Moscow: Goskomstat, 1995), 351.

44. Wegren, Russia's Food Policies and Globalization, 134.

45. World Bank, Food and Agricultural Policy Reforms in the Former USSR, 188.

46. A. Altukhov and D. Vermel', 'Prodovol'stvennoe samoobespechenie strany: sostoyanie i perspektivy', APK: ekonomika, upravlenie no. 11 (November 1997): 21.

47. William Liefert, 'Food Security in Russia: Economic Growth and Rising Incomes are Reducing Insecurity', in Food Security Assessment, GFA-15, Economic Research Service, USDA (Washington, DC: USDA, 2004), 3840.

48. Ibid., 36-37.

49. David Sedik, Sergey Sotnikov, and Doris Wiesmann, Food Security in the Russian Federation (Rome: FAO, 2003), 36-45.

50. Mikhail Maximenko and Michael Fay, 'Agricultural Situation', GAIN Report RS8002, January 14, 1998. http://www.fas.usda.gov/data. Accessed 11 February 2020.

51. Michael Fay and R. Matthewmann, 'Agricultural Situation', GAIN Report RS8025, 29 May 1998. http://www.fas.usda.gov/data. Accessed 11 February, 2020.

52. V. Semenov, 'Novyi kurs agrarnoi politiki', Economist no. 1 (January 1999): 14

53. A. Gordeev, 'Stabil'noe i dinamichnoe razvitie APK-pervostepennaia zadacha', APK: ekonomika, upravlenie no. 11 (November 2000): 8-9. 
54. Peter Engstrom, 'Unraveling the Complex Web of Global Food Trade', 4 September 2015. http://environment.umn.edu/discovery/gli/unrave ling-the-complex-web-of-global-food-trade/. Accessed 22 February 2020.

55. See S. V. Kiselev, ed., VTO $i$ sel'skoe khoziaistvo Rossii (Moscow: Teis, 2003), 57-65.

56. Author's calculations from data in Rosstat, Rossiiskii Statisticheskii ezhegodnik 2015 (Moscow: Rosstat, 2015), 633-34.

57. Jennifer Clapp, 'Food Self-Sufficiency: Making Sense of It, and When it Makes Sense', Food Policy 66 (2017): 88-96.

58. Stephen K. Wegren and Christel Elvestad, 'Russia's Food Self-Sufficiency and Food Security: An Assessment', Post-Communist Economies 30, no. 5 (2018): 565-87.

59. See for example, S. G. Golovina, I. N. Mikolaichik, L. N. Smirnova, 'Chelovecheskii capital sel'skikh territorii: demograficheskie aspekty', Ekonomika sel'skokhoziaistvennykh $i$ pererabatyvaiushchikh predpriiatii no. 8 (August 2020): 72-76.

60. Calculated from data in United States Department of Agriculture, Foreign Agricultural Service, 'Grain: World Markets and Trade', July 2020. https://apps.fas.usda.gov/psdonline/circulars/grain.pdf. Accessed 24 July 2020.

61. Ministry of Agriculture, 'Operativnyi obzor eksporta produktsii APK (dannye po sostoianiiu na 27 Dekabria 2020 goda)' 27 December 2020. http://www.mcx.gov.ru. Accessed 2 January 2021.

62. Ekspert Iug, 'Dva Rostovskikh zernotreidera poluchili 27.5\% Rossiiskoi kvoty na eksport zerna', 11 February 2021. https://agrovesti.net/news/ indst/dva-rostovskikh-zernotrejdera-poluchili-27-5-rossijskoj-kvoty-naeksport-zerna.html. Accessed 11 February 2021.

63. United States Trade Representative, 'Report on WTO Enforcement Actions: Russia', June 2015, 10. https://ustr.gov/sites/default/files/ 2015-Russia-Enforcement-Report.pdf. Accessed 5 March 2020.

64. United States Trade Representative, '2018 Report on the Implementation and Enforcement of Russia's WTO Commitments', February 2019, 21-22. https://ustr.gov/sites/default/files/Russia-2018-WTOReport.pdf. Accessed 5 March 2020.

65. Ministry of Agriculture, 'Operativnyi obzor eksporta produktsii APK (dannye po sostoianiiu na 27 Dekabria 2020 goda),' 27 December 2020. http://www.mcx.gov.ru. Accessed 2 January 2021.

66. Parlamentskaia gazeta, 'Serbiia smozhet postavliat' v EAES syr i alkogol' bez poshlin', 22 October 2020. https://kvedomosti.ru/news/httpswww-pnp-ru-economics-serbiya-smozhet-postavlyat-v-eaes-syr-i-alkogolbez-poshlin-html.html. Accessed 22 October 2020.

67. Ministry of Agriculture, 'Do 2024 goda na podderzhku eksporta APK budet napravleno svyshe 406 mlrd rublei', 26 December 2018. http:// 
mcx.ru/press-service/news/do-2024-goda-na-podderzhku-eksporta-apkbudet-napravleno-svyshe-406-mlrd-rubley/. Accessed 26 December 2018.

68. TASS, 'Ekspert: oborot torgovli v Rossii v Aprele upal na 35-45\%', 15 May 2020. https://kvedomosti.ru/news/ekspert-oborot-torgovli-vrossii-v-aprele-upal-na-35-45.html. Accessed 15 May 2020.

69. Elizaveta Litvinova, 'RSKhB prognoziruet uvelichenie doli Rossii na mirovom rynke prodovol'stviia', 14 May 2020. https://www.agroinves tor.ru/analytics/news/33697-rskhb-prognoziruet-uvelichenie-doli-rossiina-mirovom-rynke-prodovolstviya/. Accessed 14 May 2020.

\section{Selected Bibliography}

Allen, George. 'USSR Grain Imports: Past and Future'. Food Policy 12, no. 2 (1987): 90-93.

Askanas, Benedykt, Halina Askanas, Friedrich Levcik, and Michel Vale. 'The Foreign Trade of the CMEA Countries in the Second Half of the Seventies'. Eastern European Economics 17, no. 3 (1979): 77-87.

Becker, Abram S. U.S.-Soviet Trade in the 1980s, Rand Note N-2682RC. Santa Monica: Rand Corporation, 1987.

Clapp, Jennifer. Food, 2nd ed. Cambridge: Polity Press, 2016.

Cook, Edward C. 'Have the Soviets Turned the Corner on Grain Imports'? Food Policy 12, no. 2 (1987): 116-122.

Cooper, William H. 'Russia's Accession to the WTO and Implications for the United States'. Congressional Research Service Report R42085 (June 15, 2012).

Davis, Christina L. Food Fights over Free Trade: How International Institutions Promote Agricultural Trade Liberalization. Princeton: Princeton University Press, 2003.

Desai, Padma. 'Soviet Grain and Wheat Import Demands in 1981-1985'. American Journal of Agricultural Economics 64, no. 2 (1982): 312-322.

Deutsch, Robert. The Food Revolution in the Soviet Union and Eastern Europe. Boulder: Westview Press, 1986.

Doolittle, Penelope and Margaret Hughes. 'Gorbachev's Agricultural Policy: Building on the Brezhnev Food Program'. In Gorbachev's Economic Plans, vol. 2. Study Papers Submitted to the Joint Economic Committee of the Congress of the United States, Joint Economic Committee, 100th Congress, lst session. Washington, DC: Government Printing Office, 1987, 26-44.

Ennew, C. T. 'A Model of Import Demand for Grain in the Soviet Union'. Food Policy 12, no. 2 (1987): 106-115. 
Hahn, Werner. 'The Farms' Revolt and Grain Shortages in 1991'. In The 'Farmer Threat': The Political Economy of Agrarian Reform in Post-Soviet Russia, ed. Don Van Atta. Boulder: Westview, 1993, 43-54.

Hough, Jerry. Russia and the West: Gorbachev and the Politics of Reform, 2nd edn. New York: Touchstone, 1990.

Ingco, Merlinda D., and John D. Nash, eds., Agriculture and the WTO: Creating a System for Development. Washington. DC: The World Bank, 2004.

Johnson, D. Gale and Karen McConnell Brooks. Prospects for Soviet Agriculture in the 1980s. Bloomington: Indiana University Press, 1983.

Liefert, Olga, William Liefert, and Eric Luebehusen. 'Rising Grain Exports by the Formers Soviet Union Region'. Economic Research Service Report WHS13A-01 (February 2013). Available at https://www.ers.usda.gov/webdocs/ publications/39804/34899_whs13a01.pdf?v=0.

Liefert, William, Olga Liefert, and Matthew Shane. 'Russia's Growing Agricultural Imports: Causes and Outlook'. Economic Research Service Report WRS-09-04 (May 2009). Available at https://www.ers.usda.gov/webdocs/ publications/40471/9481_wrs0904_1_.pdf?v=0.

Liefert, William. 'Food Security in Russia: Economic Growth and Rising Incomes are Reducing Insecurity'. In Food Security Assessment, GFA-15, Economic Research Service, USDA. Washington, DC: USDA, 2004.

Liefert, William. 'The Food Problem in the Republics of the Former Soviet Union'. In The 'Farmer Threat': The Political Economy of Agrarian Reform in Post-Soviet Russia, ed. Don Van Atta. Boulder: Westview, 1993, 25-42.

Marer, Paul. 'The Political Economy of Soviet Relations with Eastern Europe'. In Soviet Policy in Eastern Europe, ed. Sarah Meiklejohn Terry. New Haven: Yale University Press, 1984, 155-88.

Nove, Alec. 'Soviet grain: Problems and prospects'. Food Policy 1, no. 1 (1975): 32-39.

Paarlberg, Robert L. 'The Soviet Burden on the World Food System: Challenge and Response'. Food Policy 1, no. 5 (1976): 392-404.

Porter, Jane M. and Douglas E. Bowers. A Short History of U.S. Agricultural Trade Negotiations. Staff Report no. AGES 89-23. Washington, DC: Economic Research Service, 1989. Available at www.ers.usda.gov.

Reed, Michael. International Trade in Agricultural Products. Scotts Valley, CA: CreateSpace Independent Publishing, 2016.

Sedik, David, Sergey Sotnikov, and Doris Wiesmann. Food Security in the Russian Federation. Rome: FAO, 2003.

VanGrasstek, Craig. Trade and American Leadership: The Paradoxes of Power and Wealth from Alexander Hamilton to Donald Trump. Cambridge: Cambridge University Press, 2019.

Wadekin, Karl-Eugen. 'Agriculture'. In The Soviet Union under Gorbachev, ed. Martin McCauley. New York: St. Martin’s Press, 1987, 118-34. 
Wadekin, Karl-Eugen. 'Soviet Agriculture's Dependence on the West'. Foreign Affairs 60, no. 4 (Spring 1982).

Wegren, Stephen K. 'The Impact of WTO Accession on Russian Agriculture'. Post-Soviet Affairs 28, no. 3 (2012): 296-318.

Wegren, Stephen K. 'Russian Agriculture and the WTO'. Problems of PostCommunism 54, no. 4 (2007): 46-59.

Wegren, Stephen K. Russia's Food Policies and Globalization. Lanham: Lexington Books, 2005.

Wegren, Stephen K., Alexander Nikulin and Irina Trotsuk. Food Policy and Food Security: Putting Food on the Russian Table. Lanham: Lexington Books, 2018.

Wegren, Stephen K. with Alexander Nikulin and Irina Trotsuk. Russia's Food Revolution: The Transformation of the Food System. London and New York: Routledge Publishers, 2021.

World Bank. Food and Agricultural Policy Reforms in the Former USSR: An Agenda for the Transition. Washington, DC: The World Bank, 1993.

Open Access This chapter is licensed under the terms of the Creative Commons Attribution 4.0 International License (http://creativecommons.org/licenses/ by $/ 4.0 /)$, which permits use, sharing, adaptation, distribution and reproduction in any medium or format, as long as you give appropriate credit to the original author(s) and the source, provide a link to the Creative Commons license and indicate if changes were made.

The images or other third party material in this chapter are included in the chapter's Creative Commons license, unless indicated otherwise in a credit line to the material. If material is not included in the chapter's Creative Commons license and your intended use is not permitted by statutory regulation or exceeds the permitted use, you will need to obtain permission directly from the copyright holder.

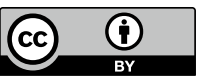

